INTERNATIONAL DESIGN CONFERENCE - DESIGN 2018

https://doi.org/10.21278/idc.2018.0345

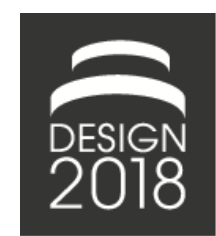

\title{
CREATIVE PATH TO PRACTICAL KNOWLEDGE - CASE OF A TRIPLE HELIX FRAMEWORK
}

\author{
V. Čok, N. Fain, R. Žavbi and N. Vukašinović
}

\begin{abstract}
The paper presents a successful Triple helix collaboration between university, industry and government that resulted in commercialisation of a sustainable new product within the aircraft industry. The case presented is a result of a government funded student project between a high-tech organisation and a mechanical engineering faculty, which fully supports the notion of how Triple helix organisations work. The solution (i.e. new product developed via Triple helix collaboration) has been prototyped, improved, manufactured and already sold to users.
\end{abstract}

Keywords: triple helix, design teams, project-based learning, design education, project management

\section{Introduction}

In the knowledge-based economy of today, companies can no longer be competitive solely on the basis of their production capital. They depend highly on their intellectual capital and often they need to look beyond the boundaries of their organisation to find it (Chesbrough, 2003). University-industry relationships are increasing in importance in today's product development, where the intellectual capital is sourced from cutting-edge university knowledge and the companies support this through the integration of their intellectual and production capital (Fain et al., 2010). Governments have acknowledged the need to support such collaborations, as they also build and grow national economies and are thus developing policies and support mechanisms that build on integrating knowledge between a variety of partners in product development.

The purpose of this paper is to present a successful Triple helix collaboration between University, Industry and Government that resulted in commercialisation of a sustainable new product within the aircraft industry. The authors build on the pioneering work of Leydesdorff and Etzkowitz (Leydesdorff and Etzkowitz, 1996; Etzkowitz and Leydesdorff, 1998), who propose that in the complex knowledgebased economies the pressure of developing successful new products is now increasingly shared between the three key parties - universities, industries and governments. Collaborations between these parties build the knowledge systems and drive faster and better developments that decrease the time to market and increase the commercialisation success of the final product.

The case presented in this paper is a result of a government funded student project between a high-tech organisation and a mechanical engineering faculty, which fully supports the notion of how Triple helix organisations work. The work of Ranga and Etzkowitz (2013) proposes that Triple Helix relationships are now becoming more complex and thus establishments of clear Triple helix systems is becoming prevailing, the case presented in this paper however showcases that simple support Triple Helix relationships still can provide progressively successful results, as long as clear project management is 
employed and accountability is shared between partners. The product that has been developed within this partnership has already generated increased demand from the market.

To build the argumentation for the simple Triple Helix partnership, this paper first looks into the developments in the literature related to Triple Helix partnerships and then presents a step by step outline of the case study. Process variables, communication structures and accountability measures are presented for the case and conclusions related to Triple Helix partnerships drawn. The paper concludes with a future outlook for the presented partnership.

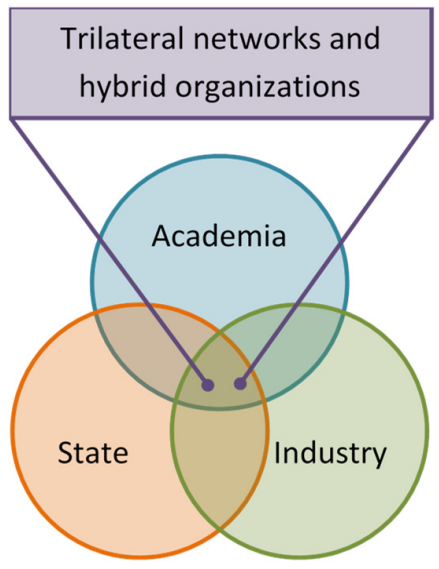

Figure 1. Triple Helix configuration - balanced Ranga and Etzkowitz (2013)

\section{Triple Helix relationships in the knowledge based economy}

Triple Helix relationships between universities, industries and governments have gained increased interest from researchers in the past decades. A variety of case study research has been presented to showcase the benefits that such relationships bring. The key presumption underpinning the Triple Helix relationships is that the institutions involved are bringing a particular skill/benefit to the partnership that enables the institution to grow in a spiral direction and at the same time support the spiral growth of the other two partners (Leydesdorff and Park, 2014). In this way the final result of the partnerships is greater than the individual sum delivery of the partners' engagements.

The Triple Helix partnerships are increasingly beneficial for Governments, as in this way the Governments can support the local improvements and growth or their economies and at the same time drive competitiveness of the nation in a wider global context (Ranga and Etzkowitz, 2013). They are beneficial for industry, as they get financial support for their developments from governmental sources and access to cutting-edge knowledge and skills from the university knowledge base (Fain et al., 2010). They are further beneficial for universities as they can provide knowledge and technology support to the industrial partner, influence policy through the partnerships and build their reputation within the economy by showcasing practical implications of the knowledge created within their programs (Etzkowitz, 2003). All of the relationships work in a reciprocal way in terms of partners also learning from each other and influencing the change within and between the participating partners.

More recent work on Triple Helix has been building on this notion of interdependency. Ranga and Etzkowitz (2013) for example propose that the Triple Helix partnerships in today's economy actually need to go beyond the simple engagements discussed above, as the stakeholders involved behave in a variety of ways and they influence the final innovation demand and outcome. This is further supported by Fain et al. (2010) who introduce the fourth helix to the relationship - the final user of the innovation. Building Triple Helix systems that are more complex in terms of components, functions and relationships between the partners has become a prevailing notion in academic literature, where measurement systems to quantify these relationships have also been proposed (i.e. Ranga and Etzkowitz, 2013; Leydesdorff and Park, 2014). Case evidence is provided to support the increased importance of 
user, relationships and the level of innovative performance of partners, however trade-offs are always present in terms of drivers that are key to individual partners (Leydesdorff and Park, 2014).

The more complex the partnerships get, the more systematic approach is needed to build and maintain the partnership success. Project management, stage-gate methodologies (Cooper, 2008) and agile approaches to product development (Cooper, 2014) have provided structured approaches to managing the variety of stakeholders involved and universities have adopted some of these practices in terms of project based learning. Project based learning is believed to be one of the most suitable pedagogies for learning product development (Christophersen et al., 1994; Dym et al., 2005; Zavbi and Vukasinovic 2014). It facilitates knowledge transfer, encourages and supports collaborative work and improves design thinking skills. It is also widely accepted that it stimulates the development of various tacit knowledge of students and teachers (Inkpen and Dinur, 1998; Eris and Leifer, 2003; Frishammar and Ylinenpää, 2007). Often, delivering such knowledge is the key driver for Universities to engage in industrial partnerships. These then enable both partners to gain their competitive goal and build their competences. The reward for the business is often monetary, whereas for the university it comes with skills developed by students and staff and reputation gained within the industrial environment. The Government supports such partnerships to use the tacit knowledge in building both local and global economy and develop country competitiveness. From this perspective, the Triple helix relationships can build on structured approach to product development rather than engage in more complex relationships.

\section{Methodology}

In this case, the government of Republic of Slovenia acted as catalyst of a triple helix relationship by opening student-academia-industry based call for projects. The main purpose of the call was to support development of students' competences, acquisition of practical knowledge and experience by implementing innovative, problem-based and team approach towards resolving real industrial or societal problems and challenges. This was done by involving them in projects that were run in the direct partnership of higher education institutions and enterprises. With the help of mentors from the educational and economic sphere, the students, within the framework of project activities, developed innovation skills, creative thinking and other competences that will enable them to move faster from education to employment.

In five months long project "Creative Path to Knowledge", students from three faculties: 5 students from the Faculty of Mechanical engineering, 2 students from the Faculty of Computer and Information Science, 1 student form the Academy of Fine Arts and Design, department of Industrial Design have developed First Charging station for electric aircraft. They were guided by three mentors. Two engineers from company and one coach from the Faculty of Mechanical engineering.

To facilitate this multidisciplinary product development process that run concurrently from several locations (at the Company and different faculties) and within narrow time constrains, the staff adapted and used CODEVE methodology (Collaborative Design in Virtual Environment). This methodology proved to be adaptive enough to different project tasks and demonstrated successfully in several industry-academia based projects of different complexity (Vukašinović and Pavković, 2017).

The design process model applied in CODEVE methodology is extended and adapted version of Pahl and Beitz method (Roozenburg and Eekels, 1995). The first phase may vary from Clarification of the task, to full Fuzzy Front-End (FFE) type of problem definition, depending on the type of project. In the FFE project type there is no initially specified product result. Once the product is defined in terms of demanded functions and further requirements, teams enter the concept generation phase. In contrary to the Pahl-Beitz model that there is no separate design phase for embodiment and detail design, at least there is no design review in between. The third major difference is that there is final, prototype making phase at the end. The purpose of prototype making phase is to teach students how to organise (prototype) production process, find part suppliers, component manufacturers, develop fully functional and fullscale prototype in order to perform demonstration of all functions and functionalities as well as to do user necessary oriented tests (Vidovics et al., 2016).

In order to best simulate a real-life situation, the project team acts like a flat-hierarchy virtual company, where the R\&D and design departments are the student team, whereas company and academic staff 
takes only some higher-level management roles, otherwise facilitates interaction between company and student teams. The members of the team are set before the project starts. Other than that, team is an autonomous entity; it is responsible for setting up internal communication and working protocols, project and data management solutions, and definitely for the timely solution of the design assignment. Team is hybrid virtual team, ideally with a range of different expertise and by nature in a geographically scattered setting.

\section{Results}

The project was carried out in several consecutive phases, making it easier to plan work on the project. At each stage, we followed a specific goal, and the results of the work served as a basis for further phases (Figure 2). The first phase was related to problem definition and research. In the second phase diverse concepts were developed. After final concept was selected we have entered into the third phase with 3D model and technical documentation, including various analyses as a major output. Due to interdisciplinarity, parallel activities at the engineering design, software development and industrial design aspect were carried out at each stage.

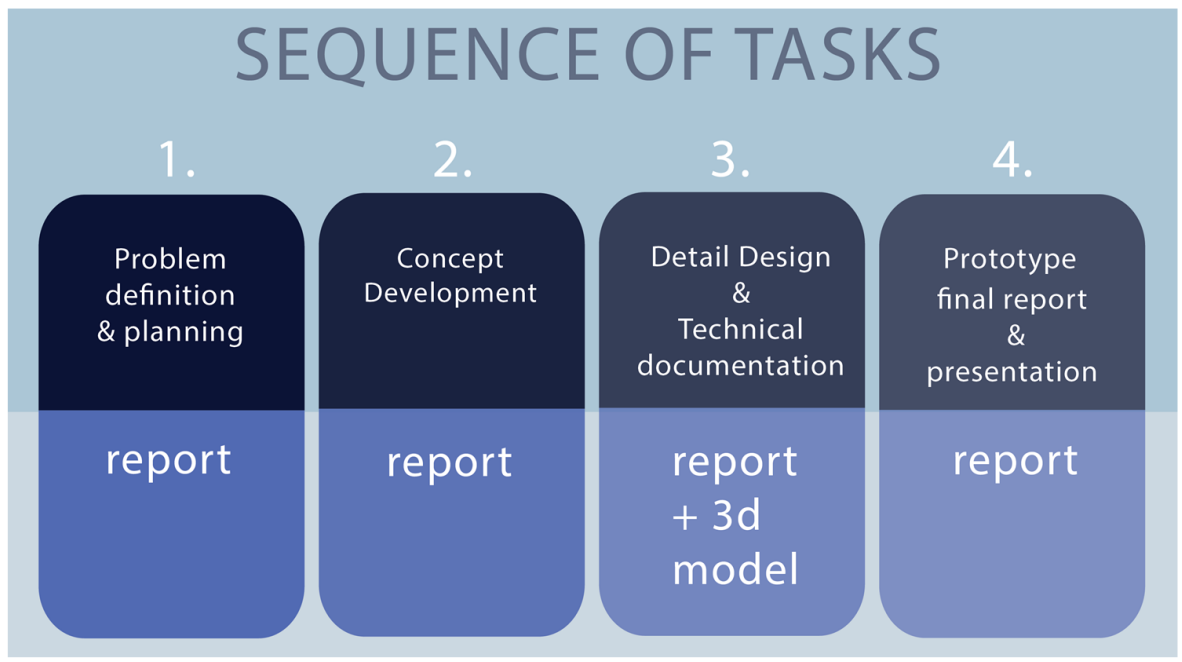

Figure 2. Consecutive phases of new product development (Čok, 2017)

\subsection{Phase 1}

In the first phase of the project, students examined the input information and the limitations associated with the project task. They examined all the properties that the product must have, and they have explored the state of the art in the domain of electric charging. Each team member explored and gathered necessary information for specific part of the product. For the design of an electric charging station, safety, user experience, etc. The students distributed a variety of topics related to the electric filling station. A content report was produced describing the problem that was investigated and the conclusions of the first phase.

\subsection{Phase 2}

In the second phase of the project, each student created three concepts. In this phase, they focused primarily on the product architecture and rough outer appearance. The concept designs (Figure 3) were presented at the company on a personal visit to their premises, where the students also viewed production of electric airplanes, and were acquainted with charging systems. The purpose of this phase was to find suitable solutions and to create three conceptual ideas (concepts) based on the visions that emerged from the use of creative techniques and brainstorming. Each of the students had to choose one of the concepts that, in their opinion, was the best fit for implementation. At the end of the phase the company representatives chose a concept. 

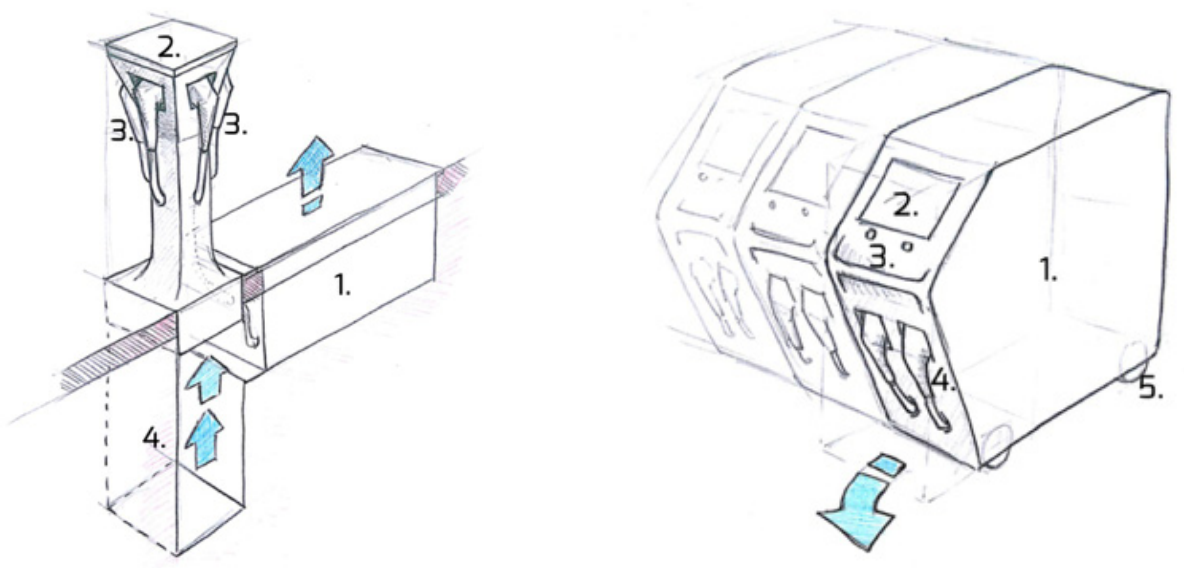

Figure 3. Study concepts of the charging station (Černač et al., 2017)

\subsection{Phase 3}

In the third phase, students converted the chosen concept into a 3D model with all the necessary dimensions and all the necessary components; of course, it took several iterations before the desired design, programming interface and the architecture were reached.

Software and user interface for charging station were created (Figure 4). Due to the changing requirements and various test results, the parts of the charging station were continuously updated. In addition to the charging module, the team also created a user interface for charging station management and an airport communication application. The purpose of this phase was to generate technical documentation of the final product. The third phase or phase of the detailed design included the entire specification of geometry, materials, and the assessment of the tolerances and the identification of all parts to be purchased or produced in-house. Additionally, documentation for in-house manufacturing and assembly was also generated. Within this phase, key issues related to production costs were also addressed.
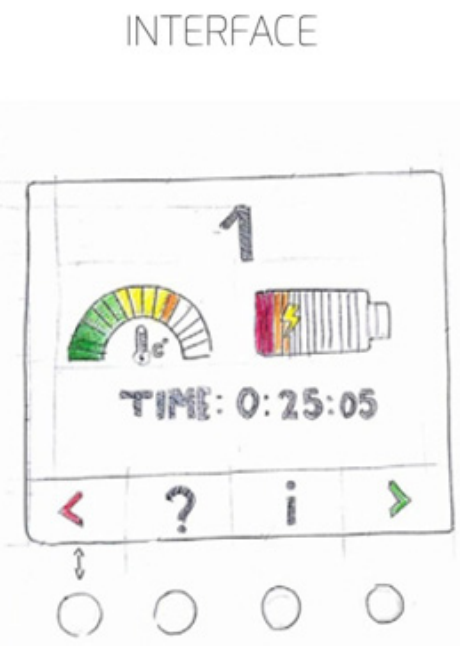

Figure 4. Concept of graphical user interface of the smart charging station for electric airplanes (Černač et al., 2017)

\subsection{Phase 4}

In the fourth phase, the students carried out necessary optimizations, taking into account some of the characteristics of the in-house manufacturing processes. The implementation phase was carried out by manufacturing of the first prototype of charging station for electric aircraft. In the final phase of the 
realization, students at the Faculty of Mechanical Engineering received manufactured parts of the charging station, which they assembled according to their plans and instructions provided by subsuppliers of the aircraft company (Figure 5). Extensive testing of all the charging station modules followed.

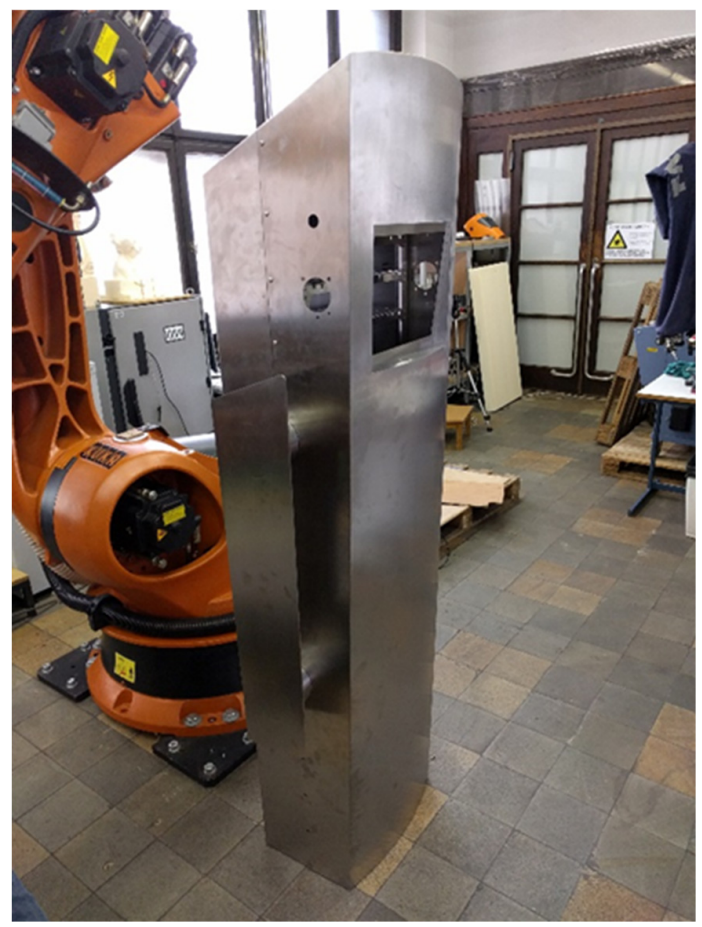

Figure 5. Building the functional prototype of the charging station

\subsection{Project conclusion}

On 30.8.2017, i.e. 6 months after the project start, the company engineers and students successfully tested the first prototype of charging station for electric Aircrafts (Figure 6). Immediately after that, the company launched the commercialisation of electric charging station to supplement their electric driven aircrafts and already collected purchase orders for several dozens of units.

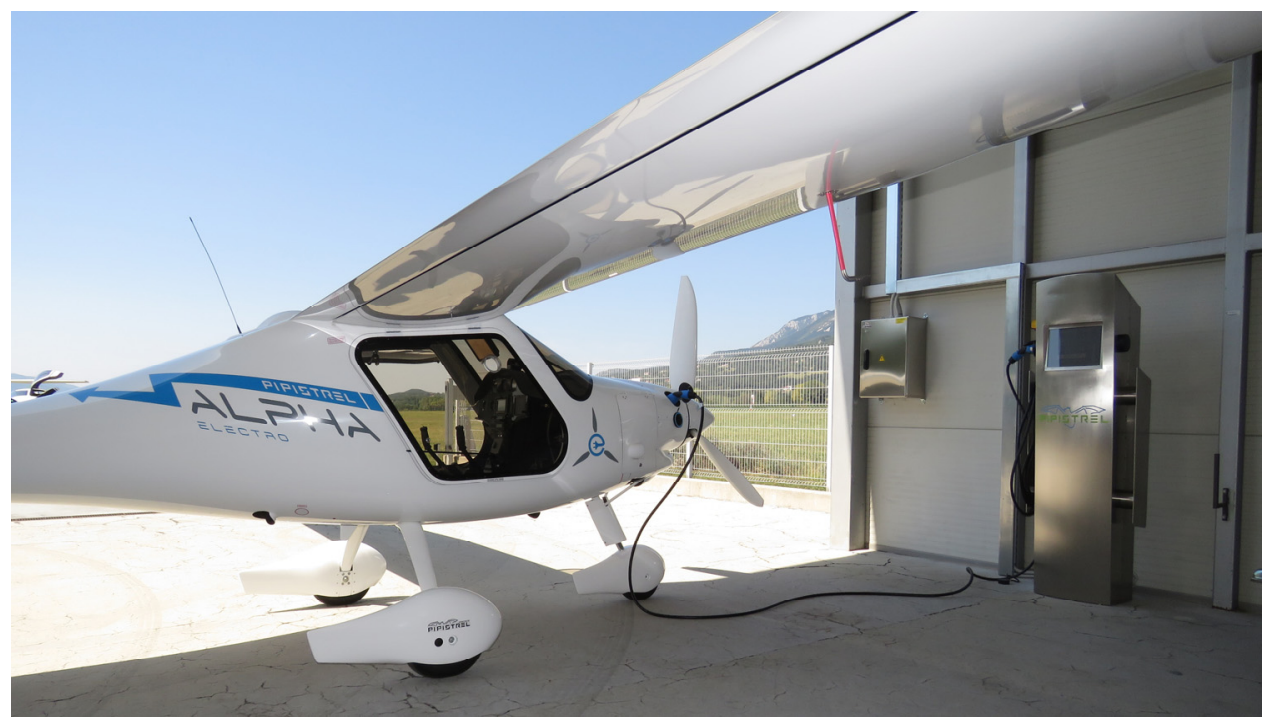

Figure 6. Application of fully developed product in real environment 


\section{Conclusion}

Triple helix relationship between university, government and industry anticipates new formats for generation, transfer and application of knowledge. The presented case is an example of successful application of the concept of Triple helix collaboration.

To students, participation in a real-world engineering project was an opportunity to engage in multidisciplinary teamwork and project-based learning, and to learn about the application of various methods/techniques to a given problem in a new format (i.e. Triple helix collaboration).

Through such and similar real-world engineering projects, the students gain initial experience of their role as future product developers, they face various real-life constraints (e.g. economic, marketing, environmental and social), they would be able to evaluate their existing technical and professional competences in new product development, and they build new ones. The authors believe that the students educated in such ways have steeper learning curve when they enter professional career.

It is also important to note that through student participation in such collaborative projects, companies are able to get to know their potential new human resources and students are also able to familiarise themselves with potential employers.

\section{Acknowledgement}

The project described in this paper and its results were co-financed by Ministry of Education, Science and Sport of Republic of Slovenia, European Social Fund and company Pipistrel d.o.o.

\section{References}

Cooper, R.G. (2014), "What's Next?: After Stage-Gate Progressive companies are developing a new generation of idea-to launch processes", Research-Technology Management, Vol. 57 No. 1, pp. 20-31. https://doi.org/10.5437/08956308X5606963

Christophersen, E., Coupe, P.S., Lenschow, R.J. and Townson, J. (1994), Evaluation of Civil and Construction Engineering Education in Denmark, Centre for Quality Assurance and Evaluation of Higher Education in Denmark, Copenhagen.

Černač, T., Križ, J., Šparovec, L., Papež, A., Rojec, E., et al. (2017), Final report: Stacionarna polnilnica za električna letala, Fakulteta za strojništvo, Ljubljana, (in Slovene).

Čok, V. (2017), Razvoj in postavitev polnilnice za električna letala za podjetje Pipistrel, Report Po Kreativni poti do praktičnega znanja 2016/17 - razvojne faze projekta, Faculty of Mechanical Engineering, Ljubljana (in Slovene).

Dym, C.L., Agogino, A.M., Eris, O., Frey, D.D. and Leifer, L.J. (2005), "Engineering Design Thinking, Teaching, and Learning”, Journal of Engineering Education, Vol. 94 No. 1, pp. 103-120. https://doi.org/10.1002/j.21689830.2005.tb00832.x

Frishammar, J. and Ylinenpää, H. (2007), "Managing Information in New Product Development: A Conceptual Review, Research Propositions and Tentative Model”, International Journal of Innovation Management, Vol. 11 No. 4, pp. 441-467. https://doi.org/10.1142/S1363919607001825

Eris, O. and Leifer, L. (2003), "Facilitating Product Development Knowledge Acquisition: Interaction between the Expert and the Team", International Journal of Engineering Education, Vol. 19 No. 1, pp. 142-152.

Etzkowitz, H. (2003), "Innovation in innovation: The Triple Helix of university -industry - government relations", Social Science Information, Vol. 42 No. 3, pp. 293-337. https://doi.org/10.1177/05390184030423002

Etzkowitz, H., Leydesdorff, L. (1998), “The endless transition: A Triple Helix of university-industry-government relations", Minerva, Vol. 36 No. 3, pp. 203-208. https://doi.org/10.1023/A:1004348123030

Fain, N., Moes, N. and Duhovnik, J. (2010), "The role of the user and the society in new product development", Strojniski Vestnik - Journal of Mechanical Engineering, Vol. 56. No. 7-8, pp. 513-522.

Inkpen, A.C. and Dinur, A. (1998), "Knowledge Management Processes and International Joint Ventures", Organization Science, Vol. 9 No. 4, pp. 454-468. https://doi.org/10.1287/orsc.9.4.454

Leydesdorff, L. and Etzkowitz, H. (1996), "Emergence of Triple Helix as a model for innovation studies", Science and Public Policy, Vol. 25, pp. 195-203.

Leydesdorff, L. and Park, H.W. (2014), "Can synergy in Triple helix relations be quantified? A review of the development of the Triple helix indicator", Triple Helix, Vol. 1 No. 4. https://doi.org/10.1186/s40604-0140004-z

Ranga, M. and Etzkowitz, H. (2013), "Triple Helix Systems: an analytical framework for innovation policy and practice in the Knowledge Society", Industry and Higher Education, Vol. 27 No. 3, pp. 237-262. https://doi.org/10.5367/ihe.2013.0165 
Roozenburg, N.F.M. and Eekels, J. (1995), Product Design: Fundamentals and Methods, Wiley, Chichester.

Vidovics, B., Vukašinović, N., Pavković, N. and Kovacevic, A. (2016), "Introduction of methodology for distributed collaborative industry-academia project based learning", Proceedings of the DESIGN 2016 / 14th International Design Conference, Dubrovnik, Croatia, 2016, The Design Society, Glasgow, pp. 2125-2136.

Vukašinović, N. and Pavković, N. (2017), "Use of virtual mobility to facilitate modern project-based NPD education", International Journal of Engineering Education, Vol. 33 No. 6(B), pp. 2008-2019.

Zavbi, R. and Vukasinovic, N. (2014), "A concept of academia-industry collaboration to facilitate the building of technical and professional competencies in new product development", International Journal of Engineering Education, Vol. 30 No. 6, pp. 1562-1578.

Dr. Nikola Vukašinović, Assistant professor

University of Ljubljana

Aškerčeva 6, 1000 Ljubljana, Slovenia

Email: nikola.vukasinovic@lecad.fs.uni-lj.si 